\title{
Ruminal biosynthesis of aromatic amino acids from arylacetic acids, glucose, shikimic acid and phenol
}

\author{
BY S. KRISTENSEN \\ Organic Chemical Laboratory, Royal Veterinary and \\ Agricultural University, Copenhagen, Denmark
}

(Received I9 fuly 1973 - Accepted ${ }_{5} 5$ October 1973)

\begin{abstract}
I. Ruminal metabolism of labelled phenylacetic acid, 4-hydroxyphenylacetic acid, indole3 -acetic acid, glucose, shikimic acid, phenol, and serine was studied in vitro by short-term incubation with special reference to incorporation rates into aromatic amino acids.

2. Earlier reports on reductive carboxylation of phenylacetic acid and indole-3-acetic acid in the rumen were confirmed and the formation of tyrosine from 4 -hydroxyphenylacetic acid was demonstrated for the first time.

3. The amount of phenylalanine synthesized from phenylacetic acid was estimated to be $2 \mathrm{mg} / \mathrm{l}$ rumen contents per $24 \mathrm{~h}$, whereas the amount synthesized from glucose might be eight times as great, depending on diet.

4. Shikimic acid was a poor precursor of the aromatic amino acids, presumably owing to its slow entry into rumen bacteria.

5. A slow conversion of phenol into tyrosine was observed.
\end{abstract}

The mechanisms of biosynthesis of rumen amino acids have been reviewed by Allison (I969). Most of these conform to known pathways, but new pathways have been established for the biosynthesis of glutamate (Emmanuel \& Milligan, 1972), the branched-chain amino acids (Allison \& Bryant, I963), phenylalanine, and tryptophan (see below). It has been shown that all these substances are synthesized by reduction, carboxylation, and amination of their corresponding fatty acids with one carbon less.

The aromatic amino acids, which all have carbon skeletons that are essential to mammals, are generally synthesized from glucose by the shikimate pathway in bacteria as well as in plants (Bohm, I965).

In experiments with whole rumen contents, Allison ( 1965$)$ found a $3.4 \%$ incorporation of $\left[\mathrm{I}^{\mathrm{I}} \mathrm{C}\right]$ phenylacetic acid into combined bacterial and protozoal protein after $\mathbf{2} \mathbf{h}$ incubation in vitro; phenylalanine was the only amino acid containing appreciable radioactivity. He reported a three to ten times greater incorporation in similar experiments with pure cultures of Bacteroides succinogenes and Ruminococcus flavefaciens. Allison \& Robinson ( 1967 ) found a $3.5 \%$ incorporation of indole- $3-\left[\mathrm{I}^{14} \mathrm{C}\right]$ acetic acid into ruminal microbial protein after $2 \mathrm{~h}$ of incubation in vitro; tryptophan was reported to contain virtually all the radioactivity of the alkaline protein hydrolysates. Of a number of pure cultures tested by them only two strains of Ruminococcus albus incorporated significant amounts of indole- 3 -acetic acid. By analogy one would expect 4-hydroxyphenylacetic acid to be incorporated into tyrosine. However, to the best knowledge of the author, experiments designed to test this hypothesis have not been published.

Recently an entirely different pathway of tyrosine biosynthesis, involving direct condensation of phenol and serine, has been described (Enei, Matsui, Yamashita, 
Table I. Precursors used and their incorporation into rumen bacteria from a cow after various periods of incubation

\begin{tabular}{|c|c|c|c|c|c|c|}
\hline \multirow[b]{2}{*}{ Precursor } & \multirow{2}{*}{$\begin{array}{c}\text { Radioactivity } \\
\text { per expt } \\
(\mu \mathrm{Ci})\end{array}$} & \multirow{2}{*}{$\begin{array}{l}\text { Specific } \\
\text { radio- } \\
\text { activity } \\
(\mathrm{mCi} / \mathrm{mmol})\end{array}$} & \multicolumn{4}{|c|}{ Incorporation into bacteria $(\%)$} \\
\hline & & & I $5 \mathrm{~min}$ & $30 \mathrm{~min}$ & $60 \mathrm{~min}$ & $90 \mathrm{~min}$ \\
\hline$\left[\mathrm{U}-{ }^{14} \mathrm{C}\right] g l u c o s e$ & $9 \cdot 6$ & xo & $10 \cdot 0$ & 7.9 & $6 \cdot 9$ & $5 \cdot 2$ \\
\hline$\left[\mathrm{G}-{ }^{14} \mathrm{C}\right]$ shikimic acid & $2 \cdot 5$ & $I \cdot 9$ & 0.3 & 0.3 & 0.4 & 0.6 \\
\hline$\left[\mathrm{I}^{14} \mathrm{C}\right]$ phenylacetic acid & $2 \cdot 8$ & 45 & 0.5 & 0.9 & $\mathrm{I} \cdot 5$ & I.9 \\
\hline $\begin{array}{l}\text { 4-Hydroxyphenyl- } \\
{\left[{ }^{1}-{ }^{14} \mathrm{C}\right] \text { acetic acid }}\end{array}$ & $2 \cdot 8$ & IO & 0.9 & $1 \cdot 6$ & 4.0 & $4 \cdot 9$ \\
\hline Indole- $3-\left[1-{ }^{14} \mathrm{C}\right]$ acetic acid & $2 \cdot 2$ & 52 & 0.2 & 0.4 & 0.7 & $\mathrm{I} \cdot 3$ \\
\hline
\end{tabular}

Okumura \& Yamada, 1972). Of 1041 strains of micro-organisms tested, they found that one Bacillus species and twenty-one strains of gram-negative bacteria possessed the relevant enzyme, tyrosine phenol lyase. Incorporation of serine into tryptophan is obligatory in tryptophan biosynthesis by the shikimate pathway. 'The ability of rumen micro-organisms to perform this reaction has been demonstrated by Candlish, Devlin \& LaCroix (1972).

The biological significance of the above observations is uncertain. Phenylacetic acid, 4-hydroxyphenylacetic acid, and indole- 3 -acetic acid are major products of ruminal catabolism of the aromatic amino acids (Scott, Ward \& Dawson, r964), and reductive carboxylation of these acids may be a means of salvaging breakdown products of fodder protein. Oltjen, Slyter, Williams \& Kern (I971) observed an increase in nitrogen retention in steers fed on purified urea and soya-bean diets upon addition of the sodium salts of 2-methylbutyrate, isovalerate, isobutyrate and phenylacetate; the salts were found to raise plasma concentrations of the branched-chain amino acids, but the concentration of phenylalanine was unaffected.

The present investigation was undertaken to evaluate the relative importance of reductive carboxylation compared with the shikimate pathway in ruminal biosynthesis of aromatic amino acids. Some experiments were included to test the possible significance of the tyrosine phenol lyase reaction.

\section{EXPERIMENTAL}

\section{Animals and incubation}

Rumen contents were obtained, by suction through a tube provided with a coarse sieve, from a fistulated heifer (Jersey, 2 years, $300 \mathrm{~kg}$ ) or a cow (Red Danish, 5 years, $500 \mathrm{~kg}$ ) and the samples were kept in a pre-warmed vacuum flask before use (maximally $0.5 \mathrm{~h}$ ). All samples were taken $3 \mathrm{~h}$ after the morning feed. The heifer was given $8 \mathrm{~kg}$ hay (experiments with glucose and shikimic acid) and the cow was given $3 \mathrm{~kg}$ oats and $8 \mathrm{~kg}$ lucerne pellets with free access to straw (experiments with arylacetic acids). All main types of rumen bacteria should be present with either diet, though the proportion of different types might vary (J. L. Wolstrup, personal communication).

Rumen contents $(5 \mathrm{ml})$ were incubated at $39^{\circ}$ under a constant stream of $\mathrm{CO}_{2}$ which was deoxygenated by passing it over copper shavings heated at $300^{\circ}$. Precursors were 


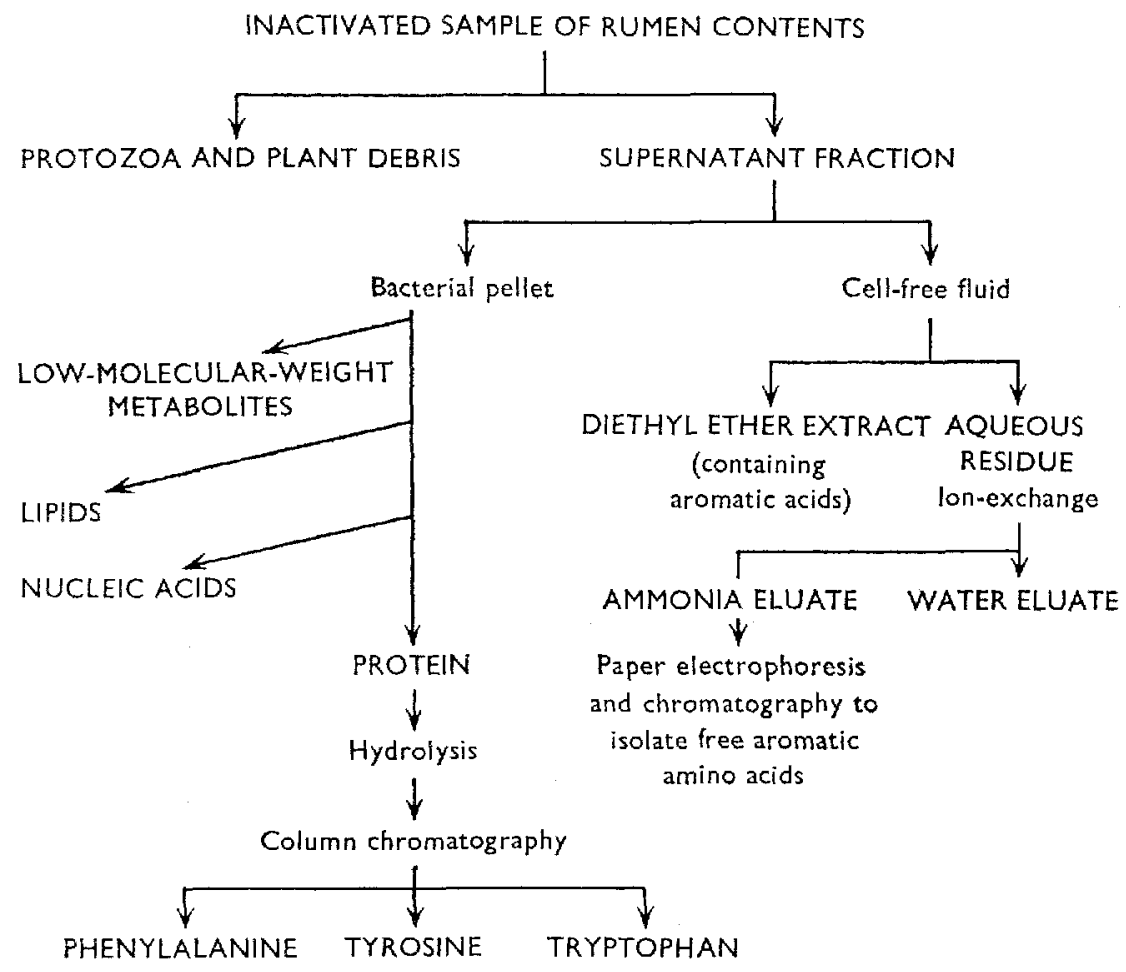

Fig. I. Schematic representation of the fractionation procedure. For details sce p. $359^{-360 .}$

added in $\mathrm{I} \cdot \mathrm{Oml}$ sterile solution containing $(\mathrm{g} / 1): \mathrm{KH}_{2} \mathrm{PO}_{4}, 3 ; \mathrm{K}_{2} \mathrm{HPO}_{4}, 3 ;\left(\mathrm{NH}_{4}\right)_{2} \mathrm{SO}_{4}$, 6; $\mathrm{NaCl}, 6$ and $\mathrm{MgSO}_{4}, 0.6$. The incubation was stopped after $15,30,60$ and $90 \mathrm{~min}$ with $\mathrm{I} \cdot \mathrm{Oml} 5 \mathrm{M}-\mathrm{NaOH}$. Blanks were included.

Radioactive chemicals were obtained from The Radiochemical Centre, Amersham, Bucks., except shikimic acid which was obtained from NEN Chemicals, Dreieichenhain, West Germany, and 4-hydroxyphenyl- $\left[\mathrm{I}^{14} \mathrm{C}\right]$ acetic acid which was prepared enzymatically from DL-tyrosine labelled in the side-chain at position 2 with ${ }^{14} \mathrm{C}$ (unpublished work). The amounts used in each experiment are given in Table $\mathrm{I}$.

\section{Fractionation scheme}

The procedure used is summarized in Fig. I.

Protozoa and plant debris were removed from the inactivated sample by centrifugation at $30 \mathrm{~g}$ for $5 \mathrm{~min}$. The pellet was freeze-dried and solubilized with $1.0 \mathrm{ml}$ Protosol $^{R}$ (NEN Chemicals, Dreieichenhain, West Germany) before counting.

The supernatant fraction was separated into bacteria and cell-free fluid by centrifugation at $18000 \mathrm{~g}$ for $\mathrm{r} 5 \mathrm{~min}$.

The bacterial pellet was washed three times with water $(2 \cdot 0 \mathrm{ml})$ and then fractionated by the method of Roberts, Cowie, Abelson, Bolton \& Britten (1955): (a) lowmolecular-weight metabolites were extracted with trichloroacetic acid $(5 \circ \mathrm{g} / 1 ; 5 \mathrm{ml})$ for $30 \mathrm{~min}$ at $5^{\circ} ;(b)$ lipids were extracted from the residue with ethanol $(75 \% \mathrm{v} / \mathrm{v}$; 
$5 \mathrm{ml})$ for $30 \mathrm{~min}$ at $45^{\circ}$, followed by diethyl ether $(2.5 \mathrm{ml})$ and ethanol $(75 \% \mathrm{v} / \mathrm{v}$; $2.5 \mathrm{ml}$ ) for $15 \mathrm{~min}$ at $45^{\circ}$ and the extracts were combined; (c) nucleic acids were extracted from the residue with trichloroacetic acid $(5 \circ \mathrm{g} / \mathrm{l} ; 5 \mathrm{ml})$ for $30 \mathrm{~min}$ on a boiling water-bath. The residue constituted the bacterial protein.

The bacterial protein was hydrolysed for $24 \mathrm{~h}$ at $120^{\circ}$ in closed tubes containing $\mathrm{Ba}(\mathrm{OH})_{2} .8 \mathrm{H}_{2} \mathrm{O}(65 \mathrm{mg})$ and water $(\mathrm{r} \cdot \mathrm{O} \mathrm{ml})$. After cooling, the $\mathrm{pH}$ was adjusted to 7 with dilute sulphuric acid; the precipitated $\mathrm{BaSO}_{4}$ was removed by centrifugation and washed three times with water $(2 \cdot 0 \mathrm{ml})$. The supernatant fraction and washings were pooled, evaporated to dryness and redissolved in $300-500 \mu \mathrm{lo} \cdot \mathrm{I} \mathrm{M}-\mathrm{HCl}$. Phenylalanine (ro $\mathrm{mg}$ ), tyrosine $(4 \mathrm{mg}$ ) and tryptophan $(4 \mathrm{mg}$ ) were added as carriers and the aromatic amino acids were isolated on a Sephadex G-10 column by the method of Kowalska (1969). The column ( $15 \times 850 \mathrm{~mm}$ ) was eluted with $0.5 \mathrm{M}-\mathrm{NaCl}$ at $24 \mathrm{ml} / \mathrm{h}$, and $4 \mathrm{ml}$ fractions were collected. The absorbance of the eluate was measured at $256 \mathrm{~nm}$ (Uvicord, LKB Instruments, Stockholm, Sweden) and all fractions were spot-tested with ninhydrin. The fractions containing phenylalanine, tyrosine and tryptophan were pooled and concentrated by evaporation.

The cell-free fluid was acidified with $5 \mathrm{M}-\mathrm{HCl}$ and the aromatic acids were extracted with diethyl ether as described by Scott et al. (1964). The combined water phases were applied to an Amberlite IR I20 ion-exchange column (IO $\times 200 \mathrm{~mm}, \mathrm{H}^{+}$-form). The column was eluted with water until the $\mathrm{pH}$ was neutral (water eluate) and then with sufficient I M- $\mathrm{NH}_{4} \mathrm{OH}$ to wash out all ninhydrin-positive substances. The ammonia eluate was concentrated by evaporation and, after the addition of small amounts of carriers, was subjected to paper electrophoresis on Whatman $3 \mathrm{MM}(2 \mathrm{kV}, 100 \mathrm{~mA}$, $2.5 \mathrm{~h})$ in formic acid solution $(8 \mathrm{og} / 1)$ in the first dimension, followed by descending paper chromatography in n-butanol-acetic acid-water (12:3:5) in the second dimension. The three aromatic amino acids migrated as virtually one spot which was located by ultraviolet light, cut out and eluted with water.

\section{Radioactivity measurements}

Samples ( $\mathrm{\circ} \circ \mathrm{ml})$ of the fractions described above were counted in a Packard TriCarb liquid scintillation spectrometer. The scintillation liquid ( $10 \mathrm{ml}$ ) was PPO (4 g) and POPOP (100 mg) in toluene $(670 \mathrm{ml})$ and Triton X-100 $(330 \mathrm{ml})$. Counting efficiency was determined by means of an external standard and all vials were counted for a sufficiently long time to reduce the counting error to less than $\mathrm{r} \cdot \mathrm{O} \%$. Only single determinations were made.

\section{Chromatographic identifications}

Samples of the protein hydrolysates and the ammonia eluates obtained by ionexchange of the cell-free fluids were subjected to two-dimensional paper chromatography on Whatman No. $\mathrm{I}$ in $n$-butanol-acetic acid-water (12:3:5) and phenolwater-conc. $\mathrm{NH}_{4} \mathrm{OH}(120: 30: \mathrm{I})$ and examined by autoradiography. Individual amino acids were identified by their $R_{F}$-values and their colour with ninhydrin $(0.2 \%$ in acetone) as reported by Smith ( $\left.195^{8}\right)$. 

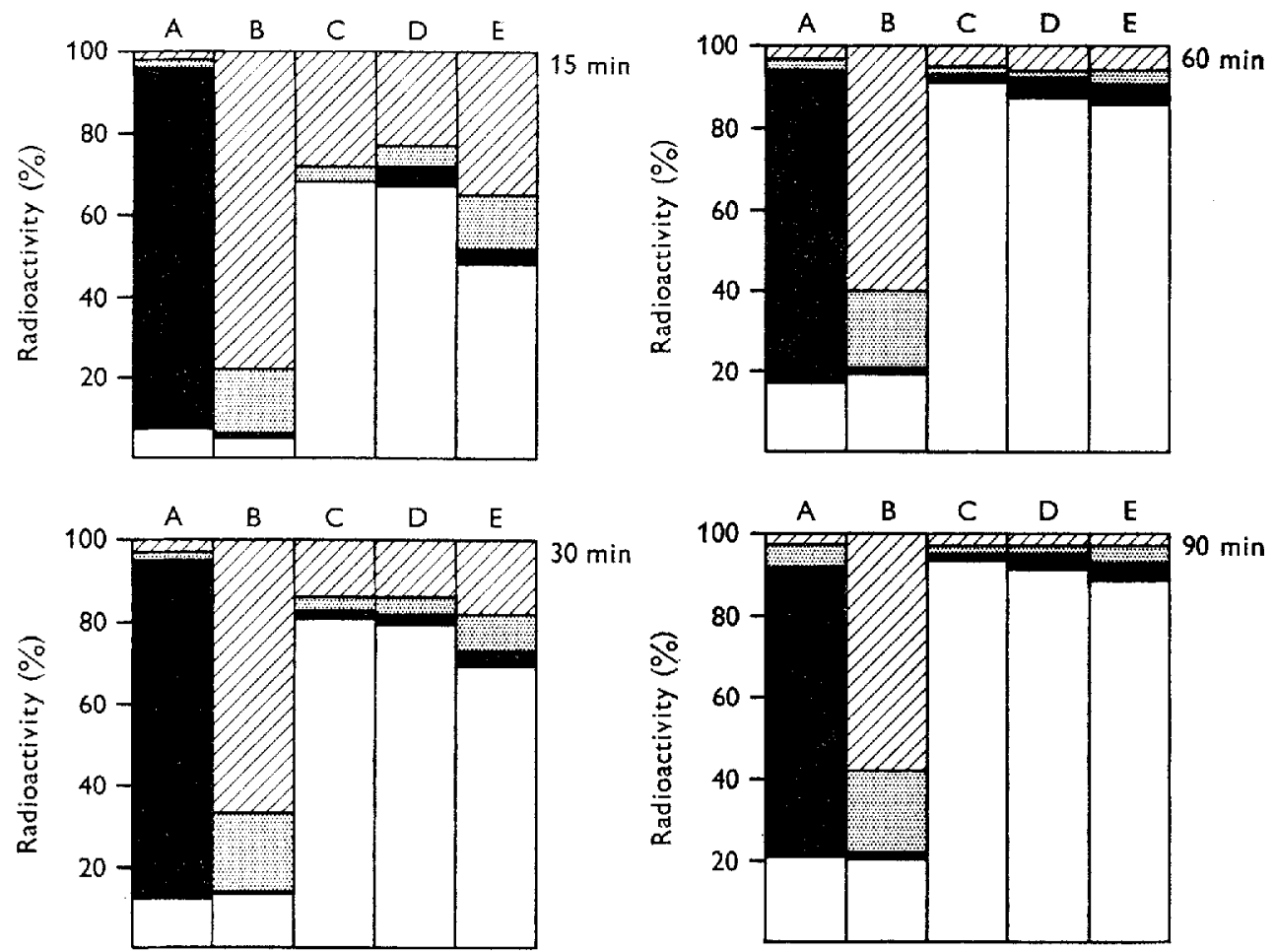

Fig. 2. Relative distribution of the radioactivity in the fractions of rumen bacteria from a cow after incubation with labelled glucose (A), shikimic acid (B), phenylacetic acid (C), 4-hydroxyphenylacetic acid (D) and indole-3-acetic acid (E) for $I 5,30,60$ and $90 \mathrm{~min}$. $\square$, low-mole-

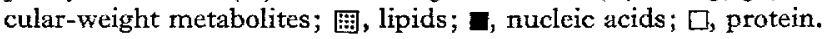

\section{RESULTS}

\section{Incorporation into bacteria}

The amounts of radioactivity incorporated into total bacterial fractions are given in Table $I$ and the relative distribution among the four components of bacterial matter obtained by the method of Roberts et al. (1955) is shown in Fig. 2.

As expected, glucose had a fast turnover rate; only $2-3 \%$ of total bacterial radioactivity was found in the fractions containing low-molecular-weight metabolites, whereas protein and especially nucleic acid fractions were labelled to a large extent. In contrast, shikimic acid was taken up very slowly and most of it remained in the fractions containing low-molecular-weight metabolites. The lipid fractions were labelled to a greater extent than the protein fractions proper. Phenylacetic acid, 4hydroxyphenylacetic acid and indole-3-acetic acid were all incorporated into protein at a high rate, whereas other fractions contained relatively little radioactivity.

\section{Incorporation into aromatic amino acids}

The radioactivity incorporated into bacterial protein hydrolysates, into the individual aromatic amino acids isolated from bacterial protein, and into total free aromatic amino acids is shown in Table 2 as a percentage of the initial radioactivity. 
Table 2. Incorporation of glucose, shikimic acid, phenylacetic acid, 4-hydroxyphenylacetic acid and indole-3-acetic acid into bacterial protein and into protein-bound and free aromatic amino acids from the rumen contents of a cow

\begin{tabular}{|c|c|c|c|c|c|c|}
\hline \multirow[b]{2}{*}{ Precursor } & \multirow{2}{*}{$\begin{array}{c}\text { Time of } \\
\text { incubation } \\
\text { (min) }\end{array}$} & \multicolumn{5}{|c|}{ Incorporation $(\%)$} \\
\hline & & $\begin{array}{l}\text { Bacterial } \\
\text { protein }\end{array}$ & Phenylalanine & Tyrosine & Tryptophan & $\begin{array}{l}\text { Free aromatic } \\
\text { amino acids }\end{array}$ \\
\hline \multirow[t]{4}{*}{ Glucose } & I5 & 0.75 & 0.020 & 0.0040 & 0.0042 & 0.044 \\
\hline & 30 & 0.97 & 0.027 & 0.0059 & 0.0062 & 0.082 \\
\hline & 60 & $I \cdot 2$ & 0.019 & 0.0074 & 0.0077 & 0.022 \\
\hline & 90 & $\mathbf{I} \mathbf{I}$ & 0.014 & 0.0062 & 0.0082 & 0.013 \\
\hline \multirow{4}{*}{$\begin{array}{l}\text { Shikimic } \\
\text { acid }\end{array}$} & I 5 & 0.014 & 0.0041 & 0.0030 & 0 & 0.015 \\
\hline & 30 & 0.033 & 0.0082 & 0.0058 & 0 & 0.036 \\
\hline & 60 & $0.08 I$ & 0.021 & 0.016 & 0 & 0.076 \\
\hline & 90 & O.II & 0.026 & 0.020 & o & 0.051 \\
\hline \multirow{4}{*}{$\begin{array}{l}\text { Phenyl- } \\
\text { acetic acid }\end{array}$} & I 5 & 0.31 & 0.23 & 0.0055 & $\circ$ & 0.12 \\
\hline & 30 & 0.75 & 0.59 & O.OIO & $\circ$ & 0.098 \\
\hline & 60 & $1 \cdot 3$ & $1 \cdot 0$ & 0.017 & $\circ$ & 0.10 \\
\hline & 90 & $1 \cdot \overline{8}$ & $1 \cdot 4$ & 0.027 & $\circ$ & 0.11 \\
\hline \multirow{4}{*}{$\begin{array}{l}\text { 4-Hydroxy } \\
\text { phenylacetic } \\
\text { acid }\end{array}$} & I 5 & 0.58 & 0.059 & 0.22 & 0.0035 & 0.057 \\
\hline & 30 & $1 \cdot 3$ & 0.14 & 0.56 & 0.0070 & 0.054 \\
\hline & 60 & 3.5 & 0.36 & $\mathrm{I} 4$ & $0.03 \mathrm{I}$ & 0.17 \\
\hline & 90 & $4 \cdot 5$ & $0: 37$ & $2 \cdot I$ & 0.029 & 0.17 \\
\hline \multirow{4}{*}{$\begin{array}{l}\text { Indole-3- } \\
\text { acetic acid }\end{array}$} & I 5 & 0.097 & 0.0034 & 0.0041 & 0.020 & 0.077 \\
\hline & 30 & 0.28 & 0.010 & 0.012 & 0.083 & 0.065 \\
\hline & 60 & 0.60 & 0.023 & 0.031 & 0.13 & 0.063 \\
\hline & 90 & $I \cdot I$ & 0.044 & 0.049 & 0.30 & 0.069 \\
\hline
\end{tabular}

With glucose, initial incorporation rates were calculated by the method of Whitelaw, Hyldgaard-Jensen, Reid \& Kay (1970), which assumes exponential depletion of substrate; the values obtained for incorporation into phenylalanine, tyrosine and tryptophan were $0.12,0.022$ and $0.026 \%$ per h, respectively. Obviously, this method could not be applied to shikimate and the arylacetic acids since a lag period was observed. The incorporation rate of shikimate was greatest in the $30-60 \mathrm{~min}$ period, whereas with the arylacetic acids a maximal rate was obtained in the $15-30$ min period (Table 2).

The incorporation into free aromatic amino acids isolated from the cell-free ruminal fluid is shown in 'Table 2. With glucose and shikimic acid, the initial incorporation was greater into free than into protein-bound aromatic amino acids, whereas the arylacetic acids gave rise to a small but more constant labelling of the former fraction. Only glucose gave visible labelling of other free amino acids. The order was aspartate $\gg$ glutamate and alanine $>$ glycine and serine.

\section{Incorporation into other fractions}

Incorporations of radioactivity into other fractions of the scheme are not tabulated, but some of the more important observations are noted.

The greater part of the radioactivity from glucose and shikimate was found in the water eluate obtained by ion-exchange of the cell-free ruminal fluid, i.e. in acidic or neutral substances. However, incubation losses, i.e. carbon dioxide production, were 
between 10 and $20 \%$ with glucose and virtually zero with shikimic acid. Indeed, when co-chromatographed with authentic shikimic acid in the solvents described by Perkins $\&$ Aronoff (1959), about $95 \%$ of the radioactivity in the water eluate in shikimate experiments proved to be unmetabolized precursor.

Label from the arylacetic acids was mainly recovered in the fraction obtained by diethyl ether extraction of the cell-free ruminal fluid. The diethyl ether extracts were examined by various chromatographic procedures, the details of which are omitted since only unmetabolized precursors were identified with ccrtainty.

\section{The tyrosine phenol lyase reaction}

Incubation was carried out with $10 \mu \mathrm{Ci}\left[\mathrm{U}-{ }^{14} \mathrm{C}\right]$ phenol $(34 \mathrm{mCi} / \mathrm{mmol})$. After $\mathrm{I} \mathrm{h}$, $0.013 \%$ of the radioactivity was incorporated into bacterial protein. The incorporation percentages into tyrosine and phenylalanine were 0.0044 and 0.00069 , respectively. Tryptophan was not labelled. When $4 \mu \mathrm{Ci}\left[3^{-14} \mathrm{C}\right]$ serine $(57 \mathrm{mCi} / \mathrm{mmol})$ were added, the incorporation percentages after $30 \mathrm{~min}$ incubation were: bacterial protein 2.5 ; phenylalanine 0.024 ; tyrosine 0.012 ; tryptophan 0.021 .

\section{DISCUSSION}

The observations of Allison (1965) and of Allison \& Robinson (1967), that phenylalanine and tryptophan can be formed from phenylacetic acid and indole-3-acetic acid respectively, were confirmed, and the analogous formation of tyrosine from 4hydroxyphenylacetic acid was demonstrated for the first time. Scott et al. (1964) reported an average value for phenylacetic acid in rumen contents of $0.04 \mathrm{mmol} / 1$. With the maximum incorporation rate determined by us ( $1.4 \%$ per $\mathrm{h}$, cf. Table 2$)$, this would be equivalent to a synthesis of approximately $2 \mathrm{mg}$ protein-bound phenylalanine per 1 in $24 \mathrm{~h}$. Reductive carboxylation of 4 -hydroxyphenylacetic acid is equally effective; that of indole-3-acetic acid is less so. The concentrations of these acids in the rumen are unknown but their formation from tyrosine and tryptophan respectively is slow (Scott et al. I964).

When phenylacetic acid was used as a precursor, phenylalanine contained about $80 \%$ of protein radioactivity (Table 2 ). The remaining $20 \%$ may be attributed to fractionation losses or fixation of labelled $\mathrm{CO}_{2}$ originating from the $\mathrm{C}_{1}$ position in phenylacetic acid or both. The labelling of tyrosine was low, as is to be expected in an anaerobic environment.

Tyrosine and tryptophan accounted for only $30-50 \%$ of total hydrolysate radioactivity in the 4-hydroxyphenylacetic acid and indole-3-acetic acid experiments. There was a significant formation of phenylalanine from 4 -hydroxyphenylacetic acid (Table 2), which means that dehydroxylation must have occurred either before or after reductive carboxylation of this precursor. The former reaction, i.e. the conversion of 4-hydroxyphenylacetic acid into phenylacetic acid, has been demonstrated with whole rumen contents by Scott et al. (I964). As shown in Table 2, indole-3-[I$\left.{ }^{14} \mathrm{C}\right]$ acetic acid was incorporated into phenylalanine and tyrosine to some extent and 4hydroxyphenyl-[ $\left[{ }^{14} \mathrm{C}\right]$ acetic acid gave labelling of tryptophan, whereas $\left[\mathrm{I}^{14} \mathrm{C}\right]$ phenyl- 


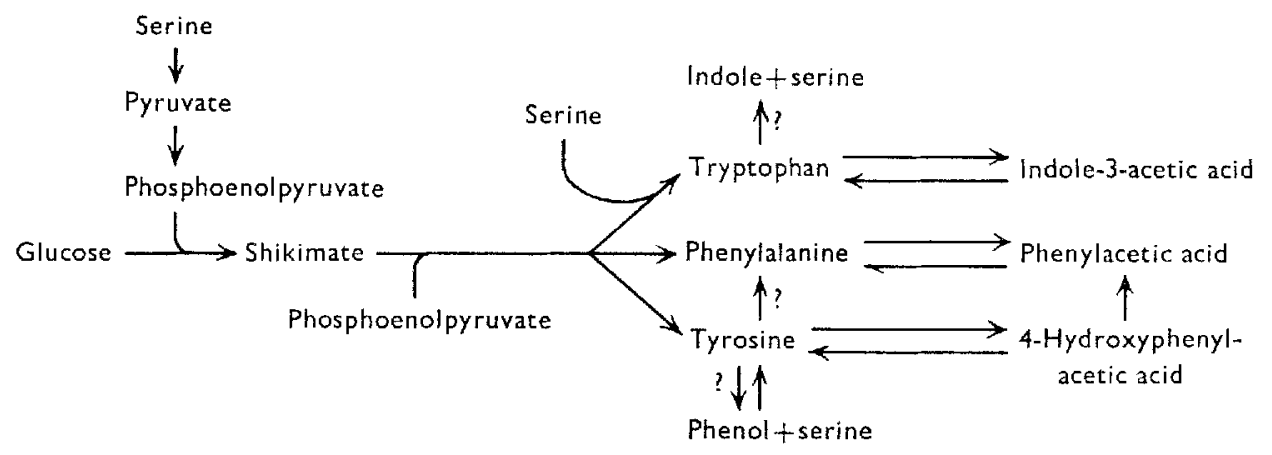

Fig. 3. Schematic representation of the pathways of rumen biosynthesis of aromatic amino acids discussed in the text.

acetic acid did not. This may be explained by the reverse reaction of the enzymes tyrosine phenol lyase and tryptophan synthase producing labelled serine (or pyruvate plus ammonia) from tyrosine and tryptophan respectively, since serine is incorporated into all three aromatic amino acids. However, this point awaits clarification.

The mechanism of reductive carboxylation is largely unknown. Allison (1969) postulated the formation of keto acids by reverse oxidative decarboxylation followed by transamination. However, the biosynthesis of glutamate from succinate is independent of thiamin pyrophosphate, and 2-hydroxy-rather than 2-keto-glutarate is an intermediate (Emmanuel \& Milligan, I972). We could not find analogous intermediates in the cell-free ruminal fluid, and the labelling of the bacterial metabolite fractions was too small to warrant their further investigation.

Shikimic acid was a poor precursor of the aromatic amino acids. This, of course, does not exclude their biosynthesis in the shikimate pathway, but indicates a hindered entry of shikimate into the bulk of rumen bacteria.

The incorporation rates of glucose can be expressed on a molar basis by multiplication by $6 / 9$ for phenylalanine and tyrosine and by $6 / 11$ for tryptophan if biosynthesis de novo is assumed. The corrected value for phenylalanine is $0.08 \%$ per $\mathrm{h}$ and is equivalent to biosynthesis of $\mathrm{I} \cdot 6-\mathrm{I} 6 \mathrm{mg} / \mathrm{l}$ per $24 \mathrm{~h}$ of this amino acid with rumen glucose concentrations in the range of $0.5-5 \mathrm{mmol} / 1$ (Ryan, r964). Thus phenylacetic acid and glucose may contribute equally to phenylalanine biosynthesis in the rumen, provided the diet is low in carbohydrate and adequate in protein. However, under such circumstances major protein catabolites such as pyruvate may take over the role of glucose as precursors of shikimate. In consequence, it is still unproven that rumen biosynthesis of aromatic amino acids by reductive carboxylation has any great nutritional importance.

There is little doubt that phenol is converted into tyrosine by rumen microorganisms, though the reaction is too slow to be of any significance. First, tyrosine accounted for one-third of the radioactivity of the bacterial protein in the experiment with labelled phenol; secondly, tyrosine was labelled to a much greater extent than phenylalanine. Serine was incorporated into the aromatic amino acids with incorporation percentages reminiscent of those obtained with glucose, with the exception that 
the relative labelling of tryptophan was greater in the serine experiment, as is to be expected when the general pathway of tryptophan synthesis is followed. Thus the incorporation of serine into phenylalanine and tyrosine must be ascribed to its catabolism to pyruvate which may be transformed into phosphoenolpyruvate and thus enter the shikimic acid pathway.

The pathways disussed above are briefly outlined in Fig. 3 .

Dr. J. L. Wolstrup in the Department of General Microbiology of this University generously provided the equipment for sampling and incubation of rumen contents. The scintillation spectrometer was given by the Danish Natural Science Research Council.

\section{REFERENCES}

Allison, M. J. (1965). Biochem. Biophys. Res. Commttn. 18, 30.

Allison, M. J. (1969). F. Anim. Sci. 29, 797.

Allison, M. J. \& Bryant, M. P. (1963). Archs Biochem. Biophys. xor, 209.

Allison, M. J. \& Robinson, I. M. (1967). Biochem. f. 102, 36 P.

Bohm, B. A. (1965). Chem. Rev. 65, 435 .

Candlish, E., Devlin, 'T. J. \& LaCroix, L. J. (1972). Can. Y. Anim. Sci. 52, 689.

Emmanuel, B. \& Milligan, L. P. (1972). Can. F. Biachem. 50, I.

Enei, H., Matsui, H., Yamashita, K., Okumura, S. \& Yamada, H. (1972). Agric. biol. Chem. 36, 1861.

Kowalska, B. (1969). Acta biochim. pol. r6, I41.

Oltjen, R. R., Slyter, L. L., Williams, E. E. Jr \& Kern, D. L. (197r). \%. Nutr. Ior, Iоr.

Perkins, H. J. \& Aronoff, S. (I959). Can. F. Biochem. Physiol. 37, I49.

Roberts, R. B., Cowie, D. B., Abelson, P. H., Bolton, E. T. \& Britten, R. J. (1955). Publs Carnegie Insin no. 607.

Ryan, R. K. (1964). Am. F. vet. Res. 25, 646.

Scott, T. W., Ward, P. F. V. \& Dawson, R. M. C. (1964). Biochem. F. 90, 12.

Smith, I. (I 958). Chromatographic Techniques vol. I. London: Heinemann.

Whitelaw, F. G., Hyldgaard-Jensen, J., Reid, R. S. \& Kay, M. G. (г970). Br. J. Nutr. 24, I 79. 